\title{
Isolation and characterization of multipotent mesenchymal stromal cells from the gingiva and the periodontal ligament of the horse
}

\author{
Niels Mensing, Hagen Gasse, Nina Hambruch, Jan-Dirk Haeger, Christiane Pfarrer and Carsten Staszyk*
}

\begin{abstract}
Background: The equine periodontium provides tooth support and lifelong tooth eruption on a remarkable scale. These functions require continuous tissue remodeling. It is assumed that multipotent mesenchymal stromal cells (MSC) reside in the periodontal ligament (PDL) and play a crucial role in regulating physiological periodontal tissue regeneration. The aim of this study was to isolate and characterize equine periodontal MSC.

Tissue samples were obtained from four healthy horses. Primary cell populations were har-vested and cultured from the gingiva, from three horizontal levels of the PDL (apical, midtooth and subgingival) and for comparison purposes from the subcutis (masseteric region). Colony-forming cells were grown on uncoated culture dishes and typical in vitro characteristics of non-human MSC, i.e. self-renewal capacity, population doubling time, expression of stemness markers and trilineage differentiation were analyzed.

Results: Colony-forming cell populations from all locations showed expression of the stemness markers CD90 and CD105. In vitro self-renewal capacity was demonstrated by colony-forming unit fibroblast (CFU-F) assays. CFUefficiency was highest in cell populations from the apical and from the mid-tooth PDL. Population doubling time was highest in subcutaneous cells. All investigated cell populations possessed trilineage differentiation potential into osteogenic, adipogenic and chondrogenic lineages.

Conclusions: Due to the demonstrated in vitro characteristics cells were referred to as equine subcutaneous MSC (eSc-MSC), equine gingival MSC (eG-MSC) and equine periodontal MSC (eP-MSC). According to different PDL levels, eP-MSC were further specified as eP-MSC from the apical PDL (eP-MSCap), eP-MSC from the mid-tooth PDL (ePMSCm) and eP-MSC from the subgingival PDL (eP-MSCsg). Considering current concepts of cell-based regenerative therapies in horses, eP-MSC might be promising candidates for future clinical applications in equine orthopedic and periodontal diseases.
\end{abstract}

\section{Background}

The periodontium represents the supporting apparatus of the tooth. It is composed of four constituents: the dental cementum, the alveolar bone, the gingiva and the periodontal ligament (PDL). The PDL is a highly cellular and vascular connective tissue which fills the periodontal space between the dental cementum and the alveolar bone. In occlusal direction the PDL is continuous with the connective tissue of the gingiva. The collagen fiber apparatus of the PDL is well adapted to anchor the tooth in the jaw $[1,2]$. During mastication, tendon-like

\footnotetext{
* Correspondence: Carsten.Staszyk@tiho-hannover.de

Institute of Anatomy, University of Veterinary Medicine Hannover, Bischofsholer Damm 15, D-30173 Hannover, Germany
}

collagen bundles of the PDL are capable of withstanding displacing forces and thus protecting the tooth from mechanical damage [3-5].

A unique feature of the PDL is an exceptional high rate of remodeling which is reflected by a very rapid collagen turnover [6-8]. It has not been fully understood whether this feature is a consequence of steady masticatory loads or if it is an inherent property of the PDL [6]. However, tissue remodeling and collagen turnover are essential prerequisites for several functional characteristics of the PDL. Under physiological conditions the PDL needs to be adjusted continuously in response to normal tooth drift and tooth eruption [1,9]. Moreover, continuous repairs and replacements of exhausted matrix

\section{Ciomed Central}


components are urgently needed as the PDL is subjected to a variety of mechanical loads during mastication [1]. Under pathological conditions, periodontal remodeling facilitates the healing and functional regeneration of injured tissue areas [10-12]. The regulation and control of periodontal remodeling and homeostasis have been the subject of several studies proposing a key role of the cellular fraction of the PDL $[13,14]$. Special attention has been paid to the question whether the different formative cell types of the periodontium (cementoblasts, PDL-fibroblasts, osteoblasts) arise from a common precursor or if specific precursor cells exist for each of the cell types [3,15]. Meanwhile, studies have demonstrated the existence of distinct cells within the PDL; which have been termed periodontal ligament stem cells (PLSC) $[16,17]$. PLSC possess the capacity of multilineage differentiation in vitro and have recently been identified in the PDL of men, e.g. [18-20], rats [21] and sheep [14]. In vivo, PLSC are thought to be the progenitors of the formative cells of the periodontium (e.g. cementoblasts, PDL-fibroblasts and osteoblasts) which in turn are required to enable continuous periodontal remodeling and regeneration [16,22].

It has been proposed that PLSC can be utilized as a cell source for the treatment of periodon-tal diseases, $i$. e. for new concepts in tissue engineering and for stem cell-based regenerative therapies [23,24]. In this regard, the equine periodontium appears to possess capacities for tissue regeneration and tissue remodeling exceeding those of other species by far. Support for this assumption can be derived from the unique dental and periodontal anatomy of the horse $[2,25]$. The equine PDL and gingiva are challenged in a very particular way. The highly abrasive diet causes a massive tooth wear rate of approx. 3 to $4 \mathrm{~mm}$ per year, with an extreme wear rate of up to $9 \mathrm{~mm}$ per year [26]. The occlusal loss of equine dental substances is compensated by a continuous eruptive movement of the tooth at an adequate rate. In comparison, brachyodont teeth of man move only between 0.02 and $0.3 \mathrm{~mm}$ per year under physiological conditions [27-29]. This remarkable physiological movement of the equine tooth requires a corresponding high rate of periodontal tissue remodeling [2]. It has already been shown that the equine PDL is characterized by a very high rate of cell proliferation and a distinct mode of collagen remodeling [30-32]. The utilization of the proposed high regenerative capacities of the equine PDL cells might offer promising new therapeutic approaches for treating typical equine disorders with high clinical relevance, i.e. treatment of destructive periodontal diseases, augmentation of the residual alveolar socket after tooth extraction and treatment of oromaxillary sinus fistula. Beyond the beneficial use for regenerative treatments in the fields of equine dentistry and equine craniofacial surgery, equine PDL cells might be also suitable for the regenerative treatment of disorders of other dense connective tissues of the equine body, in particular for the frequently injured digital flexor tendons.

The purpose of the presented study was to isolate, to culture and to characterize multipotent mesenchymal stromal cells (MSC) from the equine gingiva and from different PDL areas of the equine cheek tooth which measures up to $110 \mathrm{~mm}$. The term multipotent mesenchymal stromal cells (MSC) is currently recommended by the International Society of Cellular Therapy (ISCT) in order to denominate fibroblast-like, plastic adherent cells with defined in vitro characteristics which have been previously termed mesenchymal stem cells [33].

\section{Results}

Isolation, growth and in vitro characterization of primary cells

The first plastic adherent cells were detected between two and three days after tissue prepara-tion. Primary cell cultures reached a confluence of $70 \%-90 \%$ at day 15 (eScMSC, range 11 to 18 days), day 25 (eP-MSC, range 15 to 39 days) or day 30 (eG-MSC, range 25 to 32 days). All cultures were proven to be enriched with fibroblasts by assessing cell morphology and immunostaining profiles. When examined with inverted phase contrast microscopy the primary cells exhibited long processes and displayed a spindle-shaped fibroblast-like morphology with few cells being binucleated (Figure 1a-e). All primary cultured cells stained positive for the intermediate filament vimentin (Figure 1f). None of the primary cultures contained pan-cytokeratin or CD31 positive cells, thereby proving the absence of epithelial and endothelial cells (data not shown). The selected cells could be cultured for more than five passages and maintained stable fibroblastic morphology and growth characteristics.

\section{Self-renewal capacity \\ CFU-F assays}

CFU-F assays demonstrated that all cultures contained a subpopulation of cells capable of generating new fibroblast colonies from single cells (Figure 2). Cells from the PDL (a-c) and from the eG-MSC (d) established multiple but small new colonies, whereas eSc-MSC established fewer but larger colonies. The calculated efficiency for CFU-F varied significantly between cell cultures obtained from different sources (Figure 3). eP-MSCap and eP-MSCm possessed the highest CFU-F efficiency, i.e. $18.45 \%( \pm 4.48 \%)$ and $17.45 \%( \pm 6.69 \%)$, respectively. eP-MSCsg and eG-MSC showed CFU-F efficiency of $13.43 \%( \pm 5.13 \%)$ and $13.50 \%( \pm 6.58 \%)$. eSc-MSC exhibited the lowest CFU-F efficiency of $7.59 \%$ $( \pm 5.66 \%)$. 


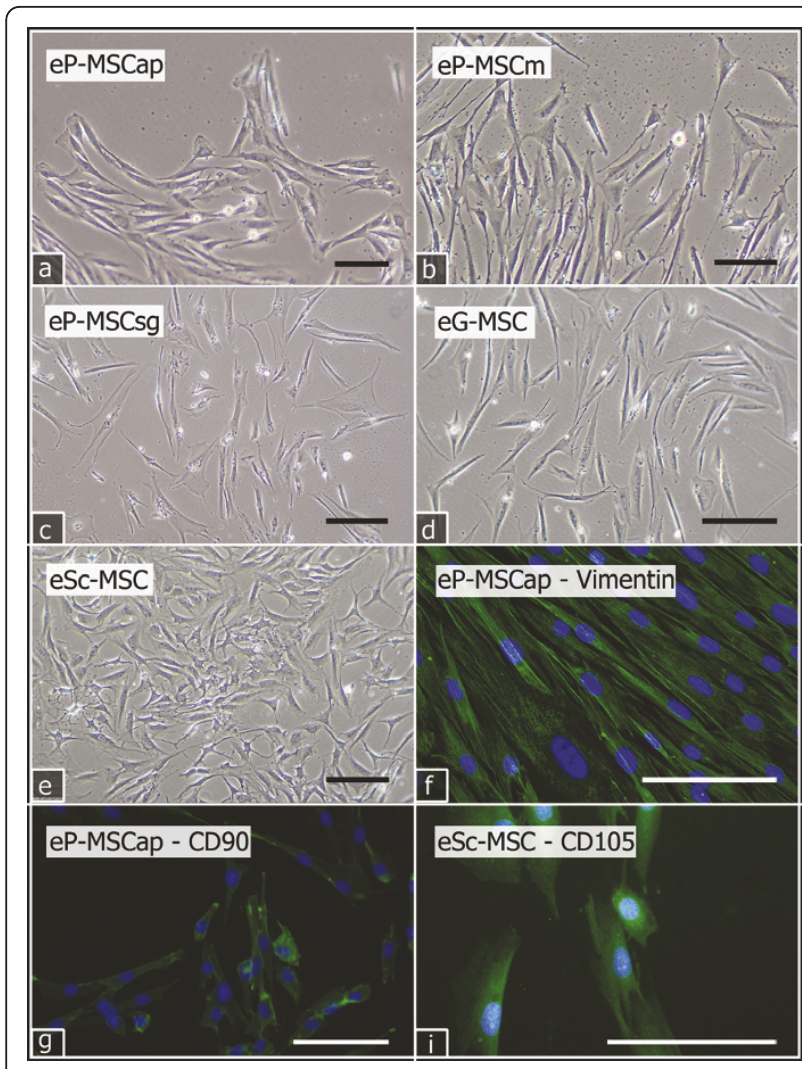

Figure 1 Primary cells. Reverse phase contrast (a-e) and fluorescent $(f)$ images of cultured primary cells (PO). All primary cells showed fibroblastic morphology and adherence to plastic culture dishes. eP-MSCap (a): day 11; eP-MSCm (b), eP-MSCsg (c), eG-MSC (d): day 18; eSc-MSC (e), day 6. All cells were positive for vimentin (green), here exemplarily shown for eP-MSCap (f). Colony forming cells from passages 2 and 3 stained positive for CD90 (green), shown for eP-MSCap (g) and for CD105 (green), shown for eSc-MSC Cell nuclei were stained with DAPI (blue). Scale bar $=100 \mu \mathrm{m}$.

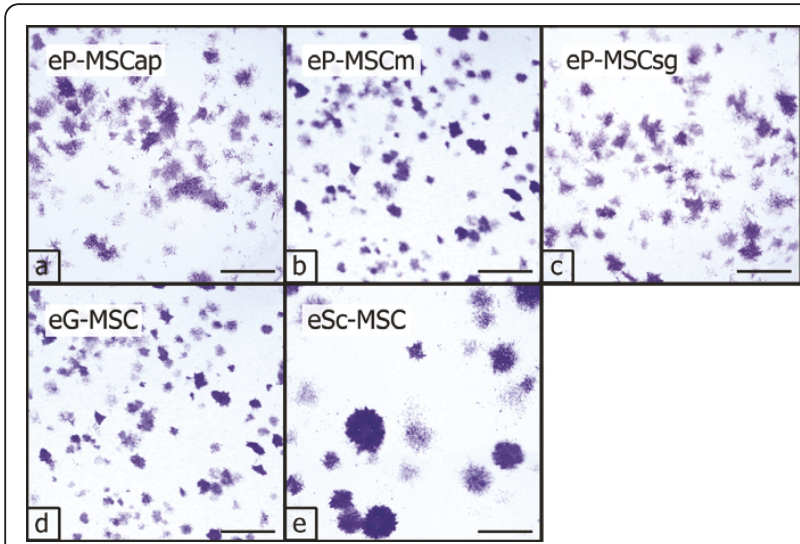

Figure 2 CFU-F assays. CFU-F assays, cell colonies (P2) were stained with $1 \%$ crystal-violet in me-thanol at day 15 of culture. eP-MSC (a-c) and eG-MSC (d) established multiple but small colonies, eSc-MSC (e) established fewer but larger colonies. Scale bar $=5 \mathrm{~mm}$.

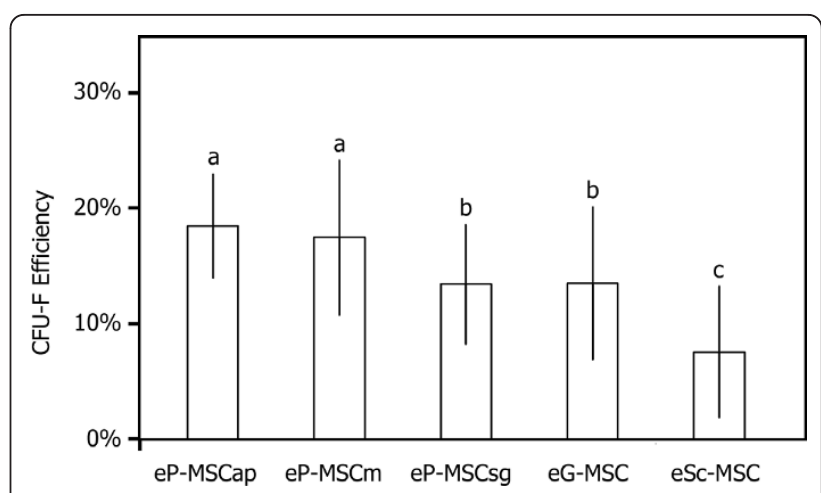

Figure 3 CFU-F efficiency. Efficiency of self renewal assessed by rate of colony formation in CFU-F assays. Columns illustrate mean CFU-F efficiency \pm standard deviation. Six independent CFU-F assays were performed for each cell populations. Statistical data analysis: multiple variance analysis with repeated measurements; Tukey posthoc-test for multiple mean value comparisons. $P$ values $<0.05$ were considered statistically significant. Significant differences among cell sources were denoted by a, b and c (all p-values < 0.019).

\section{Population doubling time}

eSc-MSC showed significantly enhanced proliferation compared to all other cultured cell populations ( $\mathrm{p}$-values $<0.0021)$. Among the periodontal cells, eP-MSCap and eP-MSCm showed significantly higher growth rates (p-values < 0.0313) than eP-MSCsg (Figure 4).

\section{Expression of stemness markers}

Colony forming cells from all localizations (eSc-MSC, eP-MSCsg, eP-MSCm, eP-MSCap and eG-MSC) expressed the stemness markers CD90 and CD105. Immunocytochemical labeling demonstrated the presence of the membrane glycoprotein CD90 and the

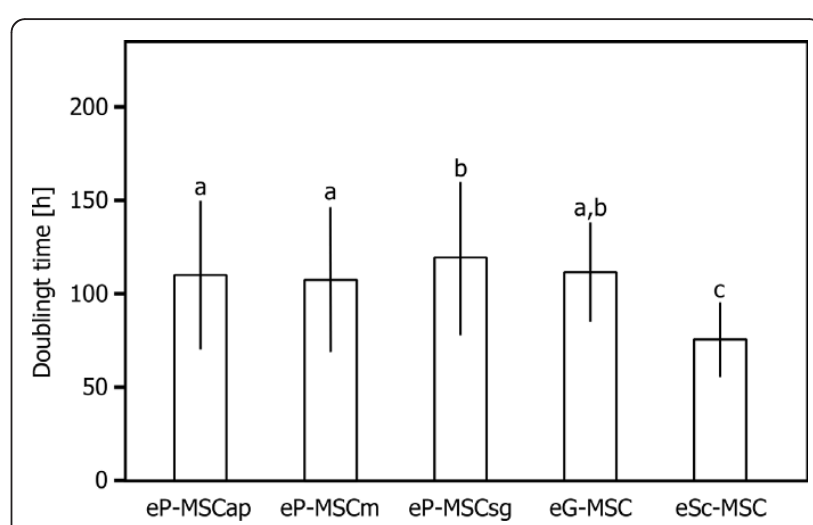

Figure 4 Doubling time efficiency. Efficiency for self renewal assessed by calculations of population doubling times. Columns illustrate mean doubling time \pm standard deviation. Three independent doubling time assays were performed for each cell populations. Statistical data analysis: multiple variance analysis with repeated measurements; Tukey post-hoc-test for multiple mean value comparisons. $P$ values $<0.05$ were considered statistically significant. Significant differences among cell sources were denoted by $a, b$ and $c$ (all p-values $<0.031$ ). 
transmembrane glycoprotein CD105 predominantly on the cell surfaces.

\section{Multilineage differentiation assays Osteogenic differentiation}

The osteogenic differentiation medium affected cell morphology and growth patterns. Almost all cultured cells changed their spindle-shaped fibroblast morphology and became stellate and irregular in shape. Instead of a confluent culture, cells formed multiple individual clusters with cells growing in several layers. All cell populations cultured in osteogenic differentiation medium produced a mineralized extracellular matrix stained positively with von Kossa. First mineralized nodules appeared at culture day 28 (Figure 5A-E). In controls cultures were kept in non-inductive culture medium, the cells preserved typical fibroblast morphology and growth characteristics with no formation of mineralized nodules in the extracellular matrix (Figure 5F).

\section{Adipogenic differentiation}

All cultures contained a subpopulation of cells capable of early stages of adipogenic differen-tiation. At day 23 of conventional adipogenic culture conditions (method 1 ) and at day three of adipogenic induction by $5 \%$ rabbit serum (method 2) these cells showed either a round and flat morphology or retained a spindle shaped phenotype. In all cases, adipogenic-induced cells contained single lipid droplets, stained orange by oil red O (Figure 6A-E).

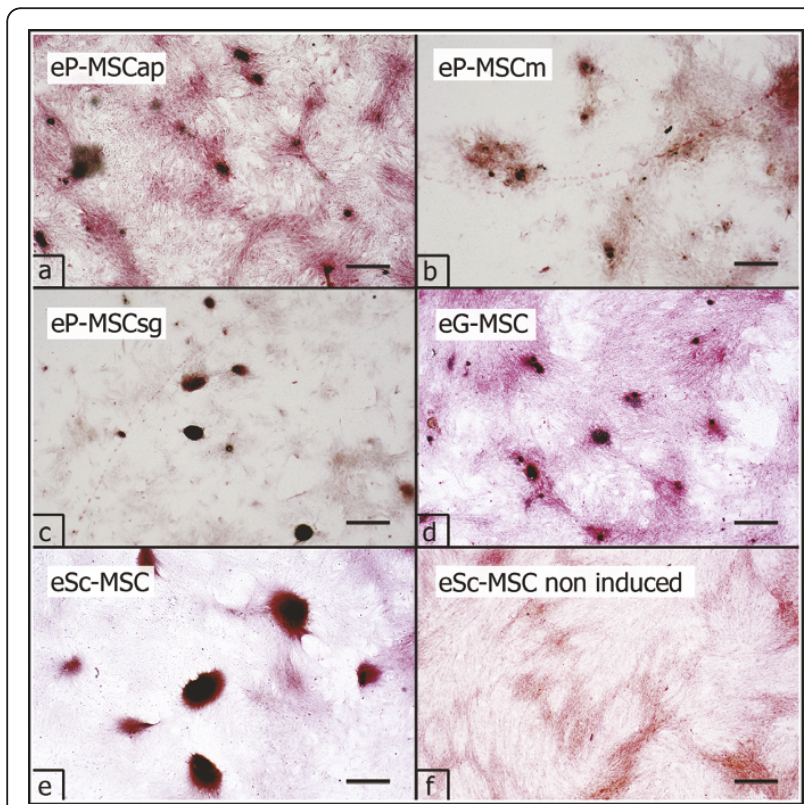

Figure 5 Osteogenic differentiation. Osteogenic differentiation (P3) as demonstrated by the presence of mineralized nodules stained black/purple with von Kossa staining (a-e). No mineralized nodules were apparent in non induced cell cultures, shown for eScMSC (f). Scale bar $=200 \mu \mathrm{m}$.

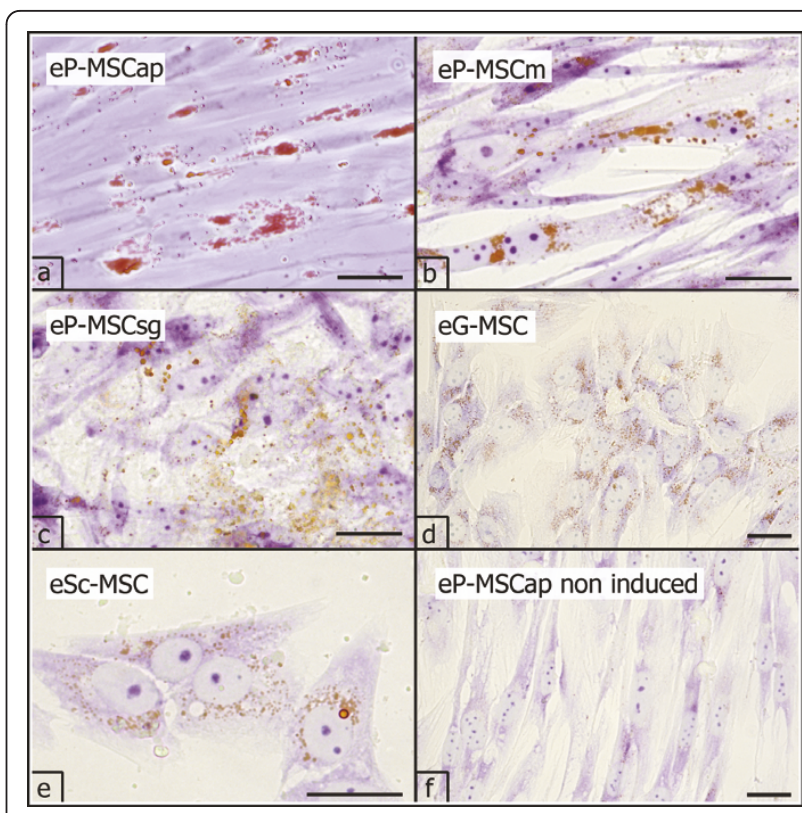

Figure 6 Adipogenic differentiation. Adipogenic differentiation (P3, P2) demonstrated by the accumulation of intracellular lipid droplets, stained orange with oil red O (a-e). No lipid droplets were present in non induced cell cultures, shown for eP-MSCap (f). Scale bar $=25 \mu \mathrm{m}$

In none of the experiments did lipid droplets fuse to large vacuoles. Cells cultivated under non inductive conditions did not accumulate lipid droplets (Figure 6F).

\section{Chondrogenic differentiation in three dimensional pellet cultures}

Cultured cell pellets did not dissolve but maintained integrity and increased gradually in size during the 21day culture period. Chondrogenic differentiation was assessed histologically by demonstrating the presence of cartilage-related matrix components in the specimens. Chondrogenic-induced pellets from all investigated cell sources showed intense purple metachromasia in toluidine blue staining, indicating a high content of sulfated proteoglycans (Figure 7A-E). Masson-Goldner-Trichrome staining revealed a high content of collagen fibers in chondrogenic-induced pellet cultures (Figure 8A-E).

In control pellets, cultivated in non-inductive medium, cells were assembled in loose ar-rangement with only few structural components in the extracellular matrix (Figure 7 and 8F).

\section{$R T-P C R$}

Further indicators of chondrogenic differentiation were assessed on mRNA level by RT-PCR. The expression of mRNA for GAPDH confirmed mRNA integrity and efficiency of reverse transcription. The predicted cDNA product of $341 \mathrm{bp}$ was amplified from all investigated 


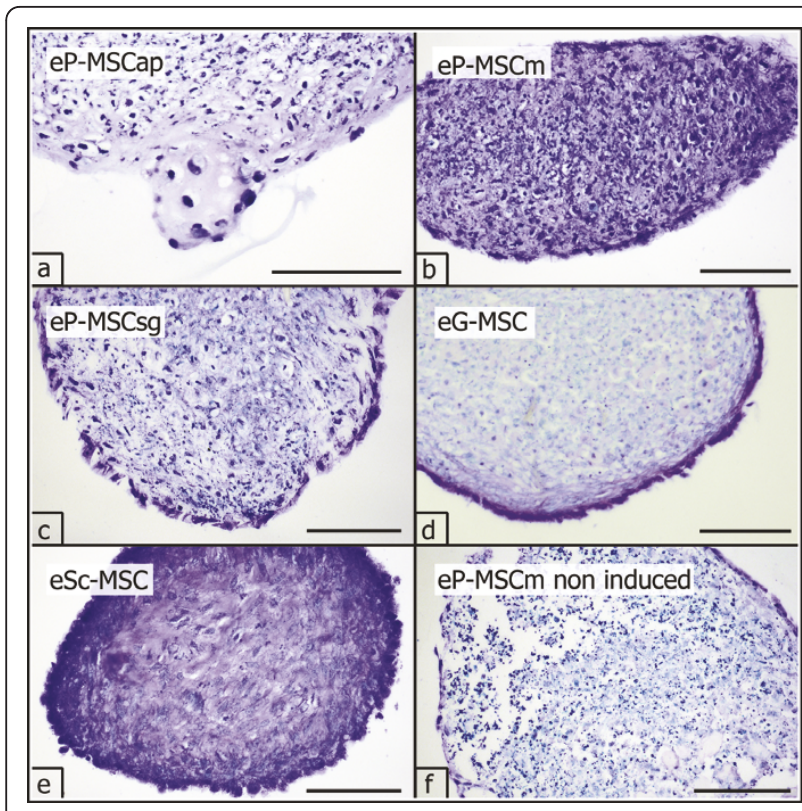

Figure 7 Chondrogenic differentiation, toluidine blue staining Chondrogenic differentiation (P3) dem-onstrated in three

dimensional pellet cultures. Sulphated proteoglycan deposition (purple metachromasia) in the extracellular matrix was assessed by toluidine blue staining (a-e). Only moderate cartilage matrix formation was present in non induced cell cultures, shown for ePMSCm (f). Scale bar $=100 \mu \mathrm{m}$.

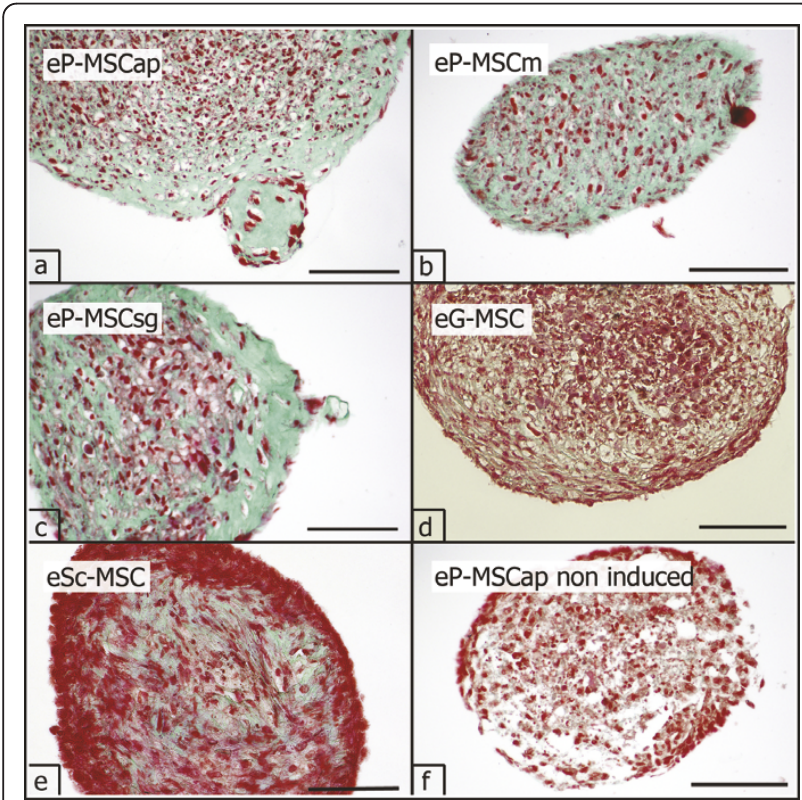

Figure 8 Chondrogenic differentiation, Masson Trichrome staining. Chondrogenic differentiation (P3) demonstrated in three dimensional pellet cultures. Collagen synthesis in the extracellular matrix (green) was confirmed with Masson Trichrome staining (a-e). Only moderate collagen formation was present in non induced cell cultures, shown for eP-MSCap (f). Scale bar $=100 \mu \mathrm{m}$. cell and tissue samples. The mRNA expression of collagen I and COMP were demonstrated in all pellet cultures, even those from control cultures kept in noninductive medium (Figure 9). Collagen I mRNA was also expressed by non-induced cells cultured in twodimensional cultures. Expression of mRNA for aggrecan was exclusively expressed by pellets cultured under inductive conditions. Amplicons for collagen II gene were expressed only in eP-MSCap and eP-MSCm (Figure 9).

\section{Discussion}

\section{The equine periodontal ligament}

The equine PDL simultaneously meets the opposing requirements of tooth support and conti-nuous tooth eruption at an exceptionally high rate under physiological conditions [25,31]. These distinct functions depend on dynamic properties which allow continuous periodontal remodeling in terms of renewal of dental cementum, periodontal ligament and alveolar bone [13,32,34]. Accordingly, periodontal remodeling is based on the presence of multiple cell types which are able to replenish the different tissues of the periodontium in a well orchestrated process $[12,35,36]$

It is widely considered that such complex processes as periodontal remodeling and functional regeneration depend on the presence of MSC within the PDL $[18,32,37]$. The presence of MSC has already been demonstrated in the PDL of men, e.g. [18-20], rats and sheep $[14,21]$ but not in the PDL of horses. To the best of our knowledge this is the first study demonstrating the presence of MSC in the equine PDL.

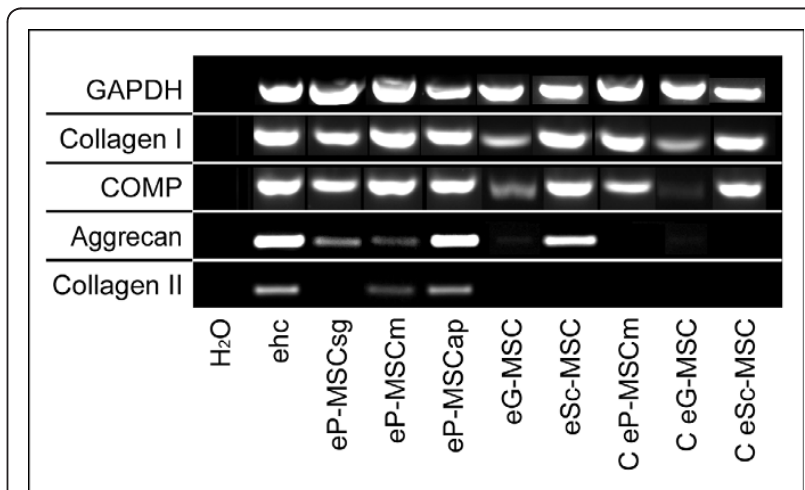

Figure 9 RT-PCR. RT-PCR analysis for indicated genes in pellet cultures (P3) after induction of chondrogenic differentiation. Cell pellets maintained in non inductive medium were used for controls (here shown for C eP-MSCm, C eG-MSC, C eSc-MSC). Extracted mRNA from equine hyaline cartilage (ehc) was used as a positive control. Note, only eP-MSCm and eP-MSCap show expression of mRNA for collagen type 2. Length of amplicons: GAPDH 341 bp, Collagen I 219 bp, COMP 238 bp, Aggrecan 147 bp, Collagen || $159 \mathrm{bp}$. 
Equine periodontal and subcutaneous MSC were identified according to distinct in vitro characteristics, i.e. plastic adherence, self-renewal capacity, expression of the stemness markers CD90 and CD105 and trilineage differentiation potency. Due to the fact that equine periodontal MSC have never been reported before, no comparative data exist. We therefore compared our results with non-equine periodontal MSC and also with nonperiodontal equine MSC.

All harvested tissue samples contained plastic adherent cells which gave rise to primary cul-tures of fibroblast-like cells. These cells matched the typical in vitro appearance of fibroblasts from the PDL of non-equine species [38-40]. The presence of vimentin confirmed an ectomesenchymal origin of the cells and distinguished them from epithelial cells and endothelial cells.

In vitro self-renewal capacity of MSC is routinely demonstrated by CFU-F assays and doubling time experiments. Obtained results provide valuable information when considering prospective utilization of the investigated MSC for therapeutical use. The CFU-F efficiency is correlated with the quantity of MSC within their original in vivo tissue [41]. The in vitro doubling time provides quantitative information about the ability of the cells to expand in culture.

\section{CFU-F assays}

Stro1+/CD146+ selected human periodontal MSC exhibited a CFU-F efficiency of $19.3 \%$ [42], which is in the same range as the values obtained for eP-MSCap (18.45\%) and for eP-MSCm (17.45\%). However, cells from other parts of the equine periodontium (eP-MSCsg and eG-MSC) possess lower CFU-F efficiencies of $13.43 \%$ and $13.50 \%$. Given that the CFU-F efficiency represents an in vitro enumeration of a clonogenic subset of MSC in vivo as demonstrated by Kuznetsov et al. (2009) [41], the apical part of the equine PDL contains more MSC than other parts of the equine periodontium. The knowledge of site-specific quantities of MSC in the equine PDL might be of practical relevance regarding protocols for MSC isolation for further investigations. For non-equine species site-specific differences in the availability of PDL MSC have not been reported so far; and it is assumed that this issue remains important only for equine periodontal research due to the enormous length of equine teeth compared to other investigated species. However, even the highest CFU-F values of our cells were lower compared to CFU-F values obtained in equine bone marrow MSC, which show mean CFU-F rates of $27 \%$ [43].

\section{Population doubling time}

Reported doubling times for equine MSC from different sources (bone marrow, adipose tissue) are in a range of
2.4 to 5 days $[44,45]$. These values are almost the same as demonstrated in equine periodontal MSC which double in number in 3.5 to 6 days. Cultured eP-MSCap and eP-MSCm proliferate at a significantly higher rate than eP-MSCsg. These in vitro findings are supplemented by corresponding in situ studies of the equine PDL. Warhonowicz et al. (2006) [31] demonstrated an elevated proliferation index in the apical level with decreasing proliferation indices towards the subgingival level. Such an asymmetric proliferation index with highest proliferative activity in the apical part of the PDL has been identified as playing a crucial role in continued tooth eruption $[46,47]$.

\section{Trilineage differentiation}

During osteogenic differentiation cells altered their shape and assembled in clusters. The cluster formation is considered a typical feature of osteogenic MSC differentiation in vitro [44]. Positive von Kossa staining confirmed the presence of calcium apatite in the extracellular matrix and thus also demonstrated successful osteogenic differentiation [48]. In addition previous studies showed that non-periodontal equine MSC formed visibly mineralized nodules within three weeks when cultured under osteogenic conditions $[43,44,48]$. In contrast our cells (ePDL-MSC, eG-MSC, eSc-MSC) did not show any presence of mineralized areas before day 28. This observation is in line with studies on nonequine periodontal MSC and suggests a suppressed capacity for extracellular matrix mineralization $[20,48,49]$.

Equine periodontal and subcutaneous MSC showed early stages of adipogenic differentiation when cultured for 23 days in a conventional differentiation medium. The adipogenic differentiation was confirmed by the detection of small intracellular lipid droplets (oil red $\mathrm{O}$ staining). Yet, a final differentiation into mature adipocytes containing large, fused lipid vacuoles was not achieved. This is in line with the findings of other authors who have reported that equine MSC did not differentiate into mature adipocytes [50]. In a second experimental setting adipogenic differentiation was induced by incubation in a differentiation medium containing rabbit serum (5\%) but no additional growth factors (i.e. dexamethasone, indomethacine, 3isobutylmethylxanthine, insulin). This method had been proven to induce adipogenic differentiation in non-periodontal equine MSC at an optimal rate with minimized detachment of cells [51]. By using rabbit serum we observed accelerated adipogenesis (only three days culture time in induction medium) as also reported by recent investigations $[44,51,52]$. However, also in these experiments a terminal adipogenic differentiation with cells containing large, fused lipid vacuoles has not been 
observed. Specific investigations addressing the adipogenic differentiation capacity of adipose derived MSC assessed the expression of peroxisome proliferator activated receptor $\gamma 2$ (PPAR $\gamma 2$ ) which plays an essential role in adipogenesis and has been widely accepted as a marker for terminal adipogenic differentiation [53,54]. Interestingly, even those equine adipose derived MSC did not display terminal adipogenic differentiation in vitro [50]. Nevertheless, although terminal adipogenic differentiation seems to be hampered in currently used in vitro culture systems for equine MSC, the demonstrated early adipogenic differentiation stage has been generally accepted to test adipogenic differentiation capacity $[43,50,55]$.

Collagens and sulphated proteoglycans are characteristic constituents of the extracellular matrix in cartilage. Their deposition in chondrogenic-induced pellet cultures can be easily demonstrated by Masson-GoldnerTrichrome and toluidine blue staining [51]. However, staining intensity is influenced by several factors and obtained data should be confirmed by determining marker mRNAs for chondrogenic differentiation [44]. We therefore conducted RT-PCR experiments and demonstrated the expression of mRNA for collagen I, COMP and aggrecan in all chondrogenic-induced cell cultures. Interestingly, only eP-MSCap and eP-MSCm expressed transcripts for collagen II. According to the current concept of in vitro chondrogenesis of MSC, collagen I and COMP become upregulated in an early stage of chondrogenic differentiation. The expression of mRNA for aggrecan represents an intermediate stage and collagen II mRNA is expressed in a final stage [56]. Thus, only eP-MSCap and eP-MSCm passed all stages of in vitro chondrogenesis, while eP-MSCsg, eG-MSC and eScMSC displayed hampered chondrogenesis in vitro. Further investigations are needed to clarify whether these in vitro results reflect in vivo characteristics of the investigated MSC.

\section{Current therapeutic use of equine MSC}

Recently, the use of so-called mesenchymal stem cells in equine medicine has gained a lot of scientific and commercial interest. However, applied cellular products have been defined according to different protocols and it is impossible to verify whether true MSC are used in different investigations $[44,57]$.

Nevertheless, supposed MSC from different tissue sources (sternal bone marrow and adipose tissue) have been therapeutically used for regenerative therapies of typical equine musculoskeletal diseases, i.e. osteoarthritis [58-60] and core lesions in the superficial digital flexor tendon [61,62]. Cell-based regenerative therapy of equine tendinopathies turned out to improve clinical outcomes compared to conservative therapies [59,63,64].
Further, cell injections resulted in significantly improved tendons histologically $[65,66]$. At present, reported outcomes are still far from the biomechanical features of a healthy tendon and the currently used regenerative therapies need to be improved. The search for a tendon-like tissue containing available MSC populations has been identified as a promising approach in order to optimize cell-based therapy of equine tendon injuries [65]. This consideration is supported by the finding that MSC form different tissue sources possess different cellular properties due to the regulatory influence of their natural local microenvironment $[67,68]$. Significantly, tendon-derived MSC show a higher capacity for tenogenic differentiation when compared with bone marrowderived MSC [49,69]. Unfortunately, the prevalence of MSC in tendons is very low and isolating suitable cell numbers appears to be impractical [69].

\section{Future prospects for the use of equine periodontal MSC}

Considering a suggested tendon-like tissue source of MSC for equine tendon therapies, the obtained equine periodontal MSC might be promising candidates for such MSC. These isolated cells definitely possess typical MSC characteristics (plastic adherence, self-renewal capacity, and trilineage differentiation potency) and are obtained from a natural niche which greatly resembles tendon tissue. The particular in vivo function of periodontal MSC is reflected in their high in vitro expression of scleraxis, a tendon-specific transcription factor. Scleraxis expression is significantly higher in human periodontal ligament MSC when compared with human bone marrow derived MSC [20,70,71].

Equine periodontal MSC might also be a useful tool in order to develop successful therapies for equine periodontal disorders. Especially in aged horses periodontal diseases are a frequent problem with an incidence of up to 60 percent, often leading to tooth loss [72]. The search for predictable periodontal regeneration utilizing periodontal MSC has also attracted a lot of interest in the field of human periodontology and several promising therapeutical strategies have been proposed in the last years (for review see Huang et al. 2009 [73]).

Yet, a major problem of the use of equine periodontal MSC arises from their limited accessi-bility. Obtaining these cells for autologous applications can not be taken in to consideration. Hence, allogenic application techniques are required. Fortunately, recent investigations confirmed that MSC avoid or suppress immunological responses, usually causing rejection of allogeneic delivered cells $[74,75]$. Such remarkable immunomodulatory properties of MSC have also been explicitly demonstrated for human periodontal MSC [76].

Moreover, allogeneic application of equine MSC in diseased tendons was already been performed in 
experimental studies without causing immune response or tumor formation $[62,77,78]$. These clinical results have recently been supplemented by in vitro investigations which demonstrated the absence of MHC class II (a crucial immune activator) on equine MSC derived from bone marrow [57].

\section{Future prospects for classification and characterization of equine periodontal MSC}

To provide an objective and comprehensive classification of the cells investigated, the rec-ommendations of the International Society for Cellular Therapies (ISCT) for the identification of non-human MSC [55] were applied. In our study the colony-forming cells showed the required characteristics, i.e. adherence to plastic culture dishes, and in vitro differentiation into osteoblastic, adipogenic and chondrogenic cells [55]. As those minimal criteria for the definition of non-human MSC were met by the isolated cells they were termed MSC.

For human MSC a third criterion is required, i.e. a well-defined profile of surface antigens [55,33]. A human MSC population should contain more than 95\% of cells which express the surface makers CD73, CD90 and CD105, and less than $2 \%$ of the cells should express CD 45, CD 34, CD14 or CD11b, CD79 $\alpha$ or CD19 and HLA class II $[55,33,79]$. Such a strict definition leads to a standardized and clear denomination of MSC and provides a substantial basis to compare results from experiments with MSC derived from different tissues of the body [55,79]. Only recently has the surface marker expression of human MSC from different dental tissues been thoroughly investigated and a useful panel of identifying marker molecules been recommended $[73,80]$.

The difficulties associated with the establishment of uniform parameters for the characteriza-tion of putative MSC in human research are even more complicated in veterinary science. Unfortunately, the surface antigen expression of equine cells, in particular of equine MSC, must still be regarded as largely unknown [50,79,81]. Nevertheless, encouraging investigations showed reactivity of available antibodies against CD90 in equine bone marrow derived MSC [43], against CD 90 in equine adipose tissue derived MSC $[44,50]$ and against CD105 in equine adipose tissue derived MSC [50]. Our results demonstrate that also MSC derived from other tissues of the equine body express CD90 and CD105 suggesting that these proteins might be used as universal markers for MSC in the horse. However, currently the panel of available equine stemness markers is very limited. The human MSC surface marker CD73 has been detected at an mRNA-level in equine MSC but not at a protein level so far [44]. Conflicting data exists for the expression of another putative MSC marker, CD13. This marker was recognized on equine MSC derived from peripheral blood but it was absent in MSC derived from adipose tissue $[82,83]$. Also demanded proof of the nonexpression of particular CD antigens is still undetermined. Guest et al. (2008) [57] confirmed the nonexpression of CD14 in equine MSC. However, others identified CD14 as an equine-specific characteristic of MSC [44]. Similar contradictory results have been reported for the expression [81] or non-expression [57] of the embryonic stem cell gene Oct4 in equine MSC. These inconsistent results emphasize the urgent need for future studies to identify and establish a useful and reliable panel of specific surface markers for equine MSC. Such surface markers would supplement and alleviate cell characterization and, even more importantly, would enable effective techniques for cell selection (immunomagnetic or fluorescence activated cell sorting). However, as long as an identifying antibody panel for equine MSC is not established, plastic adherence of colony-forming cells and trilineage differentiation capacity, should be regarded as minimal but adequate criteria for the identification of equine MSC $[55,84]$.

\section{Conclusions}

The presence of multipotent mesenchymal stromal cells within equine gingiva and periodontal ligament has been demonstrated. Protocols for cell isolation and cell expansion have been established. The obtained cell populations might be promising candidates for cellbased regenerative therapies in equine medicine, especially in the fields of craniofacial surgery, periodontal therapy and orthopedics. Further investigations are required to address the need for a panel of equine specific surface markers of MSC. In addition the cellular properties of equine periodontal MSC from different locations of the periodontium have to be compared with already characterized equine MSC from bone marrow and adipose tissue.

\section{Methods}

Animals

Samples were taken from four warm-blood horses (horse 1: 1-year-old, gelding; horse 2: 9-year-old, female; horse 3: 13-year-old, female, horse 4: 19-year-old, gelding). The animals had either previously been bought and then euthanized for the purpose of anatomical dissection courses, or had been euthanized for medical reasons at the Clinic for Horses of the University of Veterinary Medicine Hannover. The horses' ages, taken from the horses' passports, were verified by clinical examination of the dental status as recommended by Muylle (2005) [85]. All horses were free from dental or periodontal diseases. 
Immediately after euthanasia, the lower jaw was removed and samples were taken from the PDL, the gingiva, and for control purposes also from the subcutis.

\section{Gingival samples}

Samples were taken from the free gingiva at the buccal aspect of the cheek teeth region. After removing the gingival epithelium, tissue samples (sized approx. 10 $\mathrm{mm} \times 4 \mathrm{~mm} \times 2 \mathrm{~mm}$ ) were obtained from the gingival lamina propria.

\section{PDL samples}

Lower jaw segments were clamped in a bench vice, and the interdental spaces were widened to loosen the PDL of the mandibular cheek teeth. Subsequently, two fully erupted cheek teeth per horse were extracted. The intraalveolar parts of the teeth (termed reserve crown) measured up to $80 \mathrm{~mm}$. PDL tissue samples were gently separated from the surface of the teeth at three horizontal levels (subgingival, mid-tooth, and apical).

\section{Subcutaneous samples}

Samples were obtained from the subcutis of the masseteric region. After removing the skin, subcutaneous tissue samples (sized approx. $20 \mathrm{~mm} \times 5 \mathrm{~mm} \times 5 \mathrm{~mm}$ ) were harvested.

\section{Primary cell culture}

All tissue samples were placed in Dulbecco's phosphate buffered saline (DPBS) containing $100 \mathrm{U} / \mathrm{ml}$ penicillin, $100 \mu \mathrm{g} / \mathrm{ml}$ streptomycin, and $2.5 \mu \mathrm{g} / \mathrm{ml}$ amphotericin B (all constituents from PAA, Cölbe, Germany). Subsequently, samples were minced and washed three times in Dulbecco's modified Eagle's Medium (DMEM) containing 10\% fetal bovine serum, $100 \mathrm{U} / \mathrm{ml}$ penicillin, $100 \mu \mathrm{g} / \mathrm{ml}$ streptomycin, and 2.5 $\mu \mathrm{g} / \mathrm{ml}$ amphotericin B (all constituents from PAA). After a final wash, the tissue suspensions were centrifuged (500 g, $5 \mathrm{~min}$ ), and the pellets incubated in DMEM containing $2 \%$ collagenase at $37^{\circ} \mathrm{C}$ for $15 \mathrm{~min}$ (collagenase II and collagenase IV from PAA). The dissolved tissues were centrifuged once again (500 g, 5 min) and then resuspended in standard culture medium (Dulbecco's modified Eagle's Me-dium supplemented with $1 \%$ minimum essential medium [nonessential amino acids], 10\% fetal bovine serum, 0.02 $\mathrm{mM} / \mathrm{ml} \mathrm{l-glutamine,} 100 \mathrm{U} / \mathrm{ml}$ penicillin, $100 \mu \mathrm{g} / \mathrm{ml}$ streptomycin, $2.5 \mu \mathrm{g} / \mathrm{ml}$ amphotericin (all constituents from PAA). Finally, the cells were seeded into 6-well plastic culture dishes (Greiner Bio-One, Frickenhausen, Germany) and incubated in a humidified atmosphere $\left(5 \% \mathrm{CO} 2,37.0^{\circ} \mathrm{C}\right)$. Culture medium was changed after $48 \mathrm{~h}$ and thereafter every third day.

\section{Immunocytochemistry}

Prior to the experiments, the purity of fibroblast cell cultures was confirmed by staining for vimentin and absence of staining for pan-cytokeratin and CD31 (antiVimentin, clone V9; anti-Pan-cytokeratin, clone KL1; anti-CD31; all antibodies mouse, monoclonal, DCS/BioGenex, Hamburg, Germany).

The expression of the stemness markers was assessed in cell cultures from passages 2 and 3 using anti-CD90 and anti-CD105 (both Antibodies, BD Bioscience, Heidelberg, Germany). For immunostaining, cells were rinsed with DPBS and fixed with methanol-acetone (1:1) at $4^{\circ} \mathrm{C}$ for $5 \mathrm{~min}$. Afterwards non-specific binding was blocked by incubation with normal goat serum (DCS/ BioGenex, Hamburg, Germany) for $30 \mathrm{~min}$ at room temperature. Subsequently, the specimens were incubated with the primary antibodies for $12 \mathrm{~h}$ at $4^{\circ} \mathrm{C}$. Primary antibodies were used in the following dilutions: anti-Vimentin, anti-pan-cytokeratin 1:10, anti-CD31 1:30, anti-CD90 1:400, and anti-CD105 1:50. Then the probes were rinsed with DPBS and incubated with appropriate fluorochrome-conjugated secondary antibodies, i.e. goat anti-mouse (Alexa Fluor 594, Life Technologies GmbH, Darmstadt, Germany, dilution 1:1500 or FITC, Dianova, Hamburg, Germany, dilution 1:200) and goat anti-rabbit (Alexa Fluor 488, Life Technologies GmbH, Darmstadt, Germany, dilution 1:1500) for 45 min at room temperature. Cell nuclei were counterstained with DAPI or propidium iodide (PI). The nuclear staining agents were contained in mounting medium (Immunoselect Antifading Mounting Medium DAPI or Medium PI, Dianova, Hamburg, Germany). Immunoreactions were visualized with conventional fluorescence microscopy (Zeiss Axiovert 200 M, Carl Zeiss, Jena, Germany).

Controls for immunocytochemistry were prepared in three ways according to the recommen-dations of Burry (2000) [86]. Either the primary antibody was replaced by PBS, by secondary antibodies or sections were incubated with non-immune IgG (anti-rabbit IgG, Aldrich, Steinheim, Germany; anti-mouse IgG, Super Sensitive Control, DSC/Biogenex, Hamburg, Germany).

\section{Self-renewal capacity \\ Colony-forming unit-fibroblast (CFU-F) assays}

To assess the capacity and efficiency for self renewal, cells (P2) were seeded at low density and new fibroblast colonies derived from single cells were counted. This procedure was referred to as colony-forming unit-fibroblast (CFU-F) assay. Following expansion cells were seeded in 6-well culture plates (50 cells/cm2). Day 15 cultures were fixed and stained with $1 \%$ crystal-violet in $100 \%$ methanol. Stained colo-nies made up of more than 20 cells were scored as CFU and were counted. 
Calculation of the CFU-F efficiency was performed according to the formula: CFU-F efficiency $=($ counted CFU-F/cells originally seeded) $\times 100$. Routinely, six CFU-F assays were performed for each isolated cell population.

\section{Population doubling time}

Population doubling time was determined in 24-well culture plates at a density of $0.125 \times 105$ cells (P1) per well. After $24 \mathrm{~h}$ (t24h) non-adhesive cells in the medium were counted in every well and the adhesive cells (N0) were calculated. $24 \mathrm{~h}$ later $(\mathrm{t} 48 \mathrm{~h})$ in three wells the adhesive cells were counted (N48h) and the doubling time $(\mathrm{tD})$ was calculated according to the formula: $\mathrm{tD}=$ $(\log 2 \times \mathrm{t}) /(\log \mathrm{N} 48 \mathrm{~h}-\log \mathrm{N} 0)$. The determination of cells in three wells was repeated eight times in $48 \mathrm{~h}$ intervals with a change of medium on every third day. Routinely, population doubling time assays were performed in triplet for each isolated cell popu-lation.

\section{Statistical analysis}

Recorded data were statistically analyzed using a multiple variance analysis with repeated measurements. Subsequently, a Tukey post-hoc-test for multiple mean value comparisons was performed to determine statistically significant differences. $\mathrm{P}$ values $<0.05$ were considered statistically significant. Data analyses were conducted using SAS ${ }^{\circledR}$ software Version 9.1 (SAS Institute, Cary, NC, USA).

\section{Multilineage differentiation}

In order to control in vitro multilineage capacity differentiation experiments were conducted with cells from horse 1. Routinely, differentiation assays were performed in triplets for each isolated cell population.

\section{Osteogenic differentiation}

Cells (P3) were seeded in 24-well culture plates $(0.2 \times$ 105 cells/well). From the first day of incubation the cells were cultivated with osteogenic differentiation medium containing standard culture medium supplemented with $50 \mu \mathrm{g} / \mathrm{ml} \mathrm{l}$-ascorbic acid, $10 \mathrm{mM}$ b-glycerophosphate, and $10 \mathrm{nM}$ dexamethasone (all supplements from Sigma-Aldrich, Steinheim, Germany). The medium was changed every third day. 21, 28, and 35 day cultures were washed twice with DPBS and fixed in methanolacetone $(1: 1)$ at $4^{\circ} \mathrm{C}$ for $10 \mathrm{~min}$. Mineralization of the extracellular matrix served as an indicator of osteogenic differentiation. Mineralization was visualized using the von Kossa staining method [87].

\section{Adipogenic differentiation}

Cells (P3, P2) were plated in 24-well culture plates $(0.2$ $\times 105$ cells per well) and grown to confluence in culture medium containing DMEM/HamsF12 (1:1, vol/vol), 20\% fetal bovine serum, $100 \mathrm{U} / \mathrm{ml}$ penicillin and $100 \mu \mathrm{g} / \mathrm{ml}$ streptomycin. Subsequently, adipogenesis was induced by two different experimental methods.

Method 1 Cells were cultivated for three days in induction medium containing DMEM/HamsF12 (1:1, vol/vol) supplemented with $10 \%$ fetal bovine serum, $100 \mathrm{U} / \mathrm{ml}$ penicillin, $100 \mu \mathrm{g} / \mathrm{ml}$ streptomycin (supplements from PAA), $1 \mu \mathrm{M}$ dexamethasone, $100 \mu \mathrm{M}$ indomethacine, $500 \mu \mathrm{M}$ 3-isobutylmethylxanthine, $700 \mathrm{nM}$ insulin (supplements from Sigma-Aldrich). Finally, cultures were kept for one day in maintenance medium (DMEM/ HamsF12 [1:1, vol/vol] supplemented with $10 \%$ fetal bovine serum, $100 \mathrm{U} / \mathrm{ml}$ penicillin, $100 \mu \mathrm{g} / \mathrm{ml}$ streptomycin, $700 \mathrm{nM}$ insulin). This procedure was repeated four times and after the fourth cycle, cells were incubated for seven days in maintenance medium.

Method 2 Cells were cultivated for three days in culture medium (DMEM/HamsF12 [1:1, vol/vol], $100 \mathrm{U} / \mathrm{ml}$ penicillin and $100 \mu \mathrm{g} / \mathrm{ml}$ streptomycin) containing 5\% rabbit serum (PAA, Cölbe, Germany).

Adipogenic differentiation was assessed by staining intracellular accumulated lipids with $0.5 \%$ oil red O (Sigma-Aldrich). To better distinguish the lipid droplets, cell cultures were counterstained with toluidine blue.

\section{Chondrogenic differentiation}

Chondrogenesis was induced in pellet cultures. Pellet cultures were prepared from $5 \times 105$ cells (P3) placed in $15 \mathrm{ml}$ polypropylene tubes (Greiner Bio-One, Frickenhausen, Germany) and centrifuged at $500 \mathrm{~g}$ for $5 \mathrm{~min}$ at $10^{\circ} \mathrm{C}$. Chondrogenic differentiation medium was prepared supplementing standard culture medium with $1 \%$ ITS $+1,10 \mathrm{ng} / \mathrm{ml}$ transforming growth factor 3 (TGF-3, Sigma-Aldrich), $8.8 \mu \mathrm{g} / \mathrm{ml} \mathrm{l-ascorbic} \mathrm{acid} \mathrm{and} 0.1 \mu \mathrm{M}$ dexamethasone (PAA). Pellet cultures were cultivated for 21 days with medium change every third day. At day 21 the cell pellets were fixed in $10 \%$ formalin for $24 \mathrm{~h}$, and embedded in paraffin wax. Serial sections of the cell pellets were stained with Masson-Goldner-Trichrom and toluidine blue in order to demonstrate collagen content and sulfated proteoglycans within the extracellular matrix.

\section{RT-PCR}

A set of chondrocyte-related genes (collagen I, COMP, collagen II, and aggrecan [88]) were assessed by RTPCR. Total RNA and mRNA were isolated from chondrogenic induced pellet cultures, from non induced pellet cultures and from non-induced single layer cell cultures. Glyceraldehyde-3-phosphatedehydrogenase (GAPDH) mRNA was used as an internal control proving mRNA integrity and efficiency of reverse transcription. Tissue samples from equine hyaline cartilage (stifle joint), and superficial flexor tendon served as positive controls. 
Total mRNA was isolated from tissues and cultured cells using the SV Total RNA Isolation System (Promega, Mannheim, Germany) according to the manufacturer's information. Complementary DNA (cDNA) was synthesized using SuperScript ${ }^{\mathbb{R}}$ III reverse transcriptase (Invitrogen, Darmstadt, Germany). The amplification of cDNA was performed according to the manufacturer's recommendations using GoTaq ${ }^{\circledR}$ DNA Polymerase (Promega, Mannheim, Germany) and master mix volumes of $20 \mu \mathrm{L}$ containing $2 \mu \mathrm{L}$ reverse transcript product.

\section{Primer sets used and specific RT-PCR conditions were as follows}

equine collagen 1 A2: 5' - TGGTGAAGATGGTCACCCTGGAAA - 3' and 5' - TCCTGCTTGACCTGGAGTTCCATT-3' (XM_001492939), Annealing Temp.: $62.9^{\circ} \mathrm{C}, 35$ cycles, amplicon $219 \mathrm{bp}$

equine COMP: 5'-AGTGTCGCAAGGATAACTGCG TGA-3' and 5'-TCCTGATCTGTGTCCTTCTGGTCA3' (NM_001034034), Annealing Temp.: 61 ${ }^{\circ} \mathrm{C}, 35$ cycles; amplicon $238 \mathrm{bp}$

equine collagen 2A1: 5'-ATTCCTGGAGCCAAAGGATCTGCT-3' and 5'-TGAAGCCAGCAATACCAG GTTCAC-3' (NM_001081764), Annealing Temp.: 62.7 C, 35 cycles; amplicon 147 bp

equine aggrecan: 5'-TGGTGTCCTCTTCTTGTCGC TTTC-3' and 5'-ACGATACATTTGCTGTGCTTCGG C-3' (XM_001917528), Annealing Temp.: 62.7 C, 35 cycles; amplicon $159 \mathrm{bp}$

equine GAPDH: 5'-GGGTGGAGCCAAAAGGGTCATCAT-3' and 5'-AGCTTTCTCCAGGCGGCAGGTCAG-3' (XM_001488655), Annealing Temp.: 67 C, 35 cycles; am-plicon 341 bp

Amplified RT-PCR products were assessed by electrophoresis on a $2 \%$ agarose gel and visua-lized by ethidium bromide staining. A $100 \mathrm{bp}$ DNA ladder served as molecular weight marker in each gel.

\section{List of abbreviations}

MSC: Multipotent mesenchymal stromal cells; PDL: Periodontal ligament; CFU-F: Colony-forming unit fibroblast; eSc-MSC: equine subcutaneous multipotent mesenchymal stromal cells; eG-MSC: equine gingival multipotent mesenchymal stromal cells; eP-MSC: equine periodontal multipotent mesenchymal stromal cells; eP-MSCap: eP-MSC from the apical PDL; eP-MSCm: eP-MSC from the mid-tooth PDL; eP-MSCsg: eP-MSC from the subgingival PDL.

\section{Acknowledgements and Funding}

The authors thank Ms. Gudrun Wirth and Mrs. Oliver Stünkel for their skilful technical assistance.

NM was supported (personal grant) by the "Studienstiftung des deutschen Volkes"(German national academic foundation).

\section{Authors' contributions}

NM designed the study, collected and processed the specimens, assembled and analyzed the data and helped with editing and revision of the manuscript. HG contributed to the study design, evaluated the data and obtained the funding. NH helped with the PCR, contributed to data analysis and interpretation. JDH helped with the PCR, contributed to data analysis and interpretation. CP contributed to data analysis and in-terpretation. CS contributed to the study design, helped with the collection and processing of the specimens, helped with the assembling and analysis of data, drafted and wrote the manuscript. All authors read and approved the final manuscript.

Received: 10 February 2011 Accepted: 2 August 2011

Published: 2 August 2011

\section{References}

1. Berkovitz BKB: The structure of the periodontal ligament: an update. Eur $J$ Orthod 1990, 12:51-76.

2. Staszyk C, Wulff W, Jacob HG, Gasse H: The periodontal ligament of equine cheek teeth: The architecture of its collagen fiber apparatus. J Vet Dent 2006, 23:143-147.

3. Berkovitz BKB: Periodontal ligament: structural and clinical correlates. Dent Update 2004, 31:46-54.

4. Nishida E, Sasaki T, Ishikawa SK, Kosaka K, Aino M, Noguchi T, Teranaka T, Shi-mizu N, Saito M: Transcriptome database KK-Periome for periodontal ligament development: expression profiles of the extracellular matrix genes. Gene 2007, 404:70-79.

5. Nishida E, Saito M, Ishikawa S, Sasaki T, Noguchi T, Shimizu N, Teranaka T: Transcriptome analysis of extracellular matrix genes regulating periodontal ligament development. J Dent Res 2006, 5:2605.

6. Sodek J, Ferrier JM: Collagen remodelling in rat periodontal tissues: compensation for precursor reutilization confirms rapid turnover of collagen. Coll Relat Res 1988, 8:11-21.

7. Van den Bos T, Tonino GJ: Composition and metabolism of the extracellular matrix in the periodontal ligament of impeded and unimpeded rat incisors. Arch Oral Biol 1984, 29:893-897.

8. Sodek J: A comparison of the rates of synthesis and turnover of collagen and non-collagen proteins in adult rat periodontal tissues and skin using a microassay. Arch Oral Biol 1977, 22:655-665.

9. Sodek J, Overall CM, Wrana JL, Maeno M, Kubota T: Molecular Mechanisms Of Remodelling In The Periodontium: Regulation By Transforming Growth Factor-beta. In Recent Advances in Clinical Periodontology. Edited by: Ishikawa J. Edinburgh, London, New York: Elsevier Saunders; 1988:63-78.

10. Bartold PM, McCulloch CA, Narayanan AS, Pitaru S: Tissue engineering: a new paradigm for periodontal regeneration based on molecular and cell biology. Periodontol 2000 2000, 24:253-269.

11. Pitaru S, Pritzki A, Bar-Kana I, Grosskopf A, Savion N, Narayanan AS: Bone morphogenetic protein 2 induces the expression of cementum attachment protein in human periodontal ligament clones. Connect Tissue Res 2002, 43:257-264.

12. Shimono $M$, Ishikawa $T$, Ishikawa $H$, Matsuzaki $H$, Hashimoto $S$, Muramatsu T, Shima K, Matsuzaka K, Inoue T: Regulatory mechanisms of periodontal regeneration. Microsc Res Tech 2003, 60:491-502.

13. Lekic $P, M c C u l l o c h ~ C A$ : Periodontal ligament cell population: the central role of fibroblasts in creating a unique tissue. Anat Rec 1996, 245:327-341.

14. Gronthos S, Mrozik K, Shi S, Bartold PM: Ovine periodontal ligament stem cells: isolation, characterization, and differentiation potential. Calcif Tissue Int 2006, 79:310-317.

15. Lekic PC, Pender N, McCulloch CA: Is fibroblast heterogeneity relevant to the health, diseases, and treatments of periodontal tissues? Crit Rev Oral Biol Med 1997, 8:253-268.

16. Ivanovski S, Gronthos S, Shi S, Bartold PM: Stem cells in the periodontal ligament. Oral Dis 2006, 12:12358-12363.

17. Murakami $Y$, Kojima T, Nagasawa T, Kobayashi H, Ishikawa I: Novel isolation of alkaline phosphatase-positive subpopulation from periodontal ligament fibroblasts. J Periodontol 2003, 74:780-786.

18. Chen SC, Marino V, Gronthos S, Bartold PM: Location of putative stem cells in human periodontal ligament. J Periodontal Res 2006, 41:547-553.

19. Gay IC, Chen S, MacDougall M: Isolation and characterization of multipotent human periodontal ligament stem cells. Orthod Craniofac Res 2007, 10:149-160.

20. Seo BM, Miura M, Gronthos S, Bartold PM, Batouli S, Brahim J, Young M, Robey PG, Wang CY, Shi S: Investigation of multipotent postnatal stem cells from human periodontal ligament. Lancet 2004, 364:149-155.

21. Ohta S, Yamada S, Matuzaka K, Inoue T: The behavior of stem cells and progenitor cells in the periodontal ligament during wound healing as 
observed using immunohistochemical methods. J Periodontal Res 2008, 43:595-603.

22. Gould TR, Melcher AH, Brunette DM: Migration and division of progenitor cell populations in periodontal ligament after wounding. $J$ Periodontal Res 1980, 15:20-42

23. Lin NH, Menicanin D, Mrozik K, Gronthos S, Bartold PM: Putative stem cells in regenerating human periodontium. J Periodontal Res 2008, 43:514-523.

24. Lin NH, Gronthos S, Bartold PM: Stem cells and future periodontal regeneration. Periodontol 2000 2009, 51:239-251.

25. Staszyk C, Gasse H: Distinct fibro-vascular arrangements in the periodontal ligament of the horse. Arch Oral Biol 2005, 50:439-447.

26. Kirkland KD, Baker GJ, Manfra Marretta S, Eurell JA, Losonsky JM: Effects of aging on the endodontic system, reserve crown, and roots of equine mandibular cheek teeth. Am J Vet Res 1996, 57:31-38,

27. Nasjleti CE, Kowalski CJ: Stability of upper face height-total face height ratio with increasing age. J Dent Res 1975, 54:1241.

28. Forsberg CM: Facial morphology and ageing: a longitudinal cephalometric investigation of young adults. Eur J Orthod 1979, 1:15-23.

29. Sarnas KV, Solow B: Early adult changes in the skeletal and soft-tissue profile. Eur J Orthod 1979, 2:1-12

30. Lin NH, Menicanin D, Mrozik K, Gronthos S, Bartold PM: Putative stem cells in regenerating human periodontium. J Periodontal Res 2008, 43:514-523.

31. Warhonowicz M, Staszyk C, Rohn K, Gasse H: The equine periodontium as a continuously remodeling system: morphometrical analysis of cell proliferation. Arch Oral Biol 2006, 51:1141-1149.

32. Warhonowicz M, Staszyk C, Gasse H: Immunohistochemical detection of matrix metalloproteinase-1 in the periodontal ligament of equine cheek teeth. Tissue Cell 2007, 39:369-376.

33. Horwitz EM, Le Blanc K, Dominici M, Mueller I, Slaper-Crotenbach I, Marini FC, Deans RJ, Krause DS, Keating A: Clarification of the nomenclature for MSC: The International Society for Cellular Therapy position statement. Cytotherapy 2005, 7:393-395.

34. Saito Y, Yoshizawa T, Takizawa F, Ikegame M, Ishibashi O, Okuda K, Hara K, Ishi-bashi K, Obinata M, Kawashima H: A cell line with characteristics of the periodontal ligament fibroblasts is negatively regulated for mineralization and Runx2/Cbfa1/Osf2 activity, part of which can be overcome by bone morphogenetic protein-2. J Cell Sci 2002, 115:4191-4200

35. McCulloch CA, Lekic P, McKee MD: Role of physical forces in regulating the form and function of the periodontal ligament. Periodontol 2000 2000, 24:56-72

36. Reuther T, Kohl A, Komposch G, Tomakidi P: Morphogenesis and proliferation in mono- and organotypic co-cultures of primary human periodontal ligament fibroblasts and alveolar bone cells. Cell Tissue Res 2003, 312:189-196.

37. Nagatomo K, Komaki M, Sekiya I, Sakaguchi Y, Noguchi K, Oda S, Muneta T, Ishi-kawa I: Stem cell properties of human periodontal ligament cells. J Periodontal Res 2006, 41:303-310.

38. Basdra EK, Komposch G: Osteoblast-like properties of human periodontal ligament cells: an in vitro analysis. Eur J Ortho 1997, 19:615-621.

39. Gao J, Symons AL, Haase H, Bartold PM: Should cementoblasts express alkaline phosphatase activity? Preliminary study of rat cementoblasts in vitro. J Periodontol 1999, 70:951-959.

40. Piche JE, Carnes DL, Graves DT: Initial characterization of cells derived from human periodontia. J Dent Res 1989, 68:761-767.

41. Kuznetsov SA, Mankani MH, Bianco P, Robey PG: Enumeration of the colony-forming units-fibroblast from mouse and human bone marrow in normal and pathological conditions. Stem Cell Res 2009, 2:83-94.

42. Xu J, Wang W, Kapila Y, Lotz J, Kapila S: Multiple differentiation capacity of STRO-1+/CD146+ PDL mesenchymal progenitor cells. Stem Cells Dev 2009, 18:487-496.

43. Arnhold SJ, Goletz I, Klein H, Stumpf G, Beluche LA, Rohde C, Addicks K, Litzke LF: Isolation and characterization of bone marrow-derived equine mesenchymal stem cells. Am J Vet Res 2007, 68:1095-1105.

44. Braun J, Hack A, Weis-Klemm M, Conrad S, Treml S, Kohler K, Walliser U, Skutella T, Aicher WK: Evaluation of the osteogenic and chondrogenic differentiation capacities of equine adipose tissue-derived mesenchymal stem cells. Am J Vet Res 2010, 71:1228-1236.

45. Vidal MA, Kilroy GE, Lopez MJ, Johnson JR, Moore RM, Gimble JM: Characterization of equine adipose tissue-derived stromal cells: adipogenic and osteogenic capacity and comparison with bone marrow-derived mesenchymal stromal cells. Vet Surg 2007, 36:613-622.

46. Beertsen W: Migration of fibroblasts in the periodontal ligament of the mouse incisor as revealed by autoradiography. Arch Oral Biol 1981, 20:659-666.

47. Perera KAS, Tonge CH: Fibroblast cell proliferation in the mouse molar periodontal ligament. J Anat 1981, 133:77-90.

48. McDuffee LA, Anderson GI, Wright GM, Ryan DA: In vitro heterogeneity of osteogenic cell populations at various equine skeletal sites. Can J Vet Res 2006, 70:277-284

49. Jo YY, Lee HJ, Kook SY, Choung HW, Park JY, Choung JH, Kim ES, Yang HC, Choung PH: Isolation and characterization of postnatal stem cells from human dental tissues. Tissue Eng 2007, 13:767-773.

50. Pascucci L, Mercati F, Marini C, Ceccarelli P, Dall'Aglio C, Pedini V, Gargiulo AM: Ultrastructural morphology of equine adipose-derived mesenchymal stem cells. Histol Histopathol 2010, 25:1277-1285.

51. Giovannini S, Brehm W, Mainil-Varlet P, Nesic D: Multilineage differentiation potential of equine blood-derived fibroblast-like cells. Differentiation 2008, 76:118-129.

52. Janderova L, McNeil M, Murrell AN, Mynatt RL, Smith SR: Human mesenchymal stem cells as an in vitro model for human adipogenesis. Obes Res 2003, 11:65-74.

53. Hu E, Tontonoz P, Spiegelman BM: Transdifferentiation of myoblasts by the adipogenic transcription factors PPARy and C/EBPa. Proc Nat Acad SCi 1995, 92:9856-9860

54. Huang Y, Yang X, Wu Y, Jing W, Cai X, Tang W, Liu L, Liu Y, Grottkau BE, Lin Y: Gamma-secretase inhibitor induces adipogenesis of adiposederived stem cells by regulation of Notch and PPAR-gamma. Cell Prolif 2010, 43:147-56.

55. Dominici M, Le Blanc K, Mueller I, Slaper-Cortenbach I, Marini F, Krause D, Deans R, Keating A, Prockop D, Horwitz E: Minimal criteria for defining multipotent mesenchymal stromal cells. The International Society for Cellular Therapy position statement. Cytotherapy 2006, 8:315-317.

56. Barry F, Boynton RE, Liu B, Murphy JM: Chondrogenic differentiation of mesenchymal stem cells from bone marrow: differentiation-dependent gene expression of matrix components. Exp Cell Res 2001, 268:189-200.

57. Guest DJ, Ousey JC, Smith MR: Defining the expression of marker genes in equine mesenchymal stromal cells. Stem Cells and Cloning: Advances and Applications 2008, 1:1-9.

58. Frisbie DD, Kisiday JD, Kawcak CE, Werpy NM, Mcllwraith CW: Evaluation of adipose-derived stromal vascular fraction or bone marrow-derived mesenchymal stem cells for treatment of osteoarthritis. J Orthop Res 2009, 27:1675-1680.

59. Frisbie DD, Smith RK: Clinical update on the use of mesenchymal stem cells in equine orthopaedics. Equine Vet J 2010, 42:86-89.

60. Wilke MM, Nydam DV, Nixon AJ: Enhanced early chondrogenesis in articular defects following arthroscopic mesenchymal stem cell implantation in an equine model. J Orthop Res 2007, 25:913-925.

61. Smith RK, Korda M, Blunn GW, Goodship AE: Isolation and implantation of autologous equine mesenchymal stem cells from bone marrow into the superficial digital flexor tendon as a potential novel treatment. Equine Vet J 2003, 35:99-102.

62. Guest DJ, Smith MR, Allen WR: Monitoring the fate of autologous and allogeneic mesenchymal progenitor cells injected into the superficial digital flexor tendon of horses: preliminary study. Equine Vet J 2008, 40:178-181.

63. Smith RK: Mesenchymal stem cell therapy for equine tendinopathy Disabil Rehabil 2008, 30:1752-1758.

64. Fortier LA, Smith RK: Regenerative medicine for tendinous and ligamentous injuries of sport horses. Vet Clin North Am Equine Pract 2008, 24:191-201.

65. Richardson LE, Dudhia J, Clegg PD, Smith R: Stem cells in veterinary medicine-attempts at regenerating equine tendon after injury. Trends Biotechnol 2007, 25:409-416.

66. Schnabel LV, Lynch ME, van der Meulen MC, Yeager AE, Kornatowski MA, Nixon AJ: Mesenchymal stem cells and insulin-like growth factor-I geneenhanced mesenchymal stem cells improve structural aspects of healing in equine flexor digitorum superficialis tendons. J Orthop Res 2009, 27:1392-1398. 
67. Sakaguchi Y, Sekiya I, Yagishita K, Muneta T: Comparison of human stem cells derived from various mesenchymal tissues: superiority of synovium as a cell source. Arthritis Rheum 2005, 52:2521-2529.

68. Khan WS, Johnson DS, Hardingham TE: The potential of stem cells in the treatment of knee cartilage defects. Knee 2010, 17:369-374.

69. Bi Y, Ehirchiou D, Kilts TM, Inkson CA, Embree MC, Sonoyama W, Li L, Leet Al, Seo BM, Zhang L, Shi S, Young MF: Identification of tendon stem/ progenitor cells and the role of the extracellular matrix in their niche. Nat Med 2007, 13:1219-1227.

70. Fujii S, Maeda H, Wada N, Tomokiyo A, Saito M, Akamine A: Investigating a clonal human periodontal ligament progenitor/stem cell line in vitro and in vivo. J Cell Physiol 2008, 215:743-749.

71. Silverio KG, Benatti BB, Casati MZ, Sallum EA, Nociti FH: Stem cells: potential therapeutics for periodontal regeneration. Stem Cell Rev 2008, 4:13-19.

72. Klugh DO: Equine periodontal disease. Clin Tech Equine Pract 2005, 4:135-147.

73. Huang GT, Gronthos S, Shi S: Mesenchymal stem cells derived from dental tissues vs. those from other sources: their biology and role in regenerative medicine. J Dent Res 2009, 88:792-806.

74. Griffin MD, Ritter T, Mahon BP: Immunological Aspects of Allogeneic Mesenchymal Stem Cell Therapies. Hum Gene Ther 2010, 21:1641-1655.

75. Tyndall A, Walker UA, Cope A, Dazzi F, De Bari C, Fibbe W, Guiducci S, Jones S, Jorgensen C, Le Blanc K, Luyten F, McGonagle D, Martin I, BocelliTyndall C, Pennesi G, Pistoia V, Pitzalis C, Uccelli A, Wulffraat N, Feldmann M: Immunomodulatory properties of mesenchymal stem cells: a review based on an interdisciplinary meeting held at the Kennedy Institute of Rheumatology Division, London, UK, 31 October 2005. Arthritis Res Ther 2007, 9:301.

76. Wada N, Menicanin D, Shi S, Bartold PM, Gronthos S: Immunomodulatory properties of human periodontal ligament stem cells. J Cell Physiol 2009, 219:667-676.

77. Guest DJ, Smith MR, Allen WR: Equine embryonic stem-like cells and mesenchymal stromal cells have different survival rates and migration patterns following their injection into damaged superficial digital flexor tendon. Equine Vet J 2010, 42:636-642.

78. Del Bue M, Ricco S, Ramoni R, Conti V, Gnudi G, Grolli S: Equine adiposetissue derived mesenchymal stem cells and platelet concentrates: their association in vitro and in vivo. Vet Res Commun 2008, 32(Suppl 1):S51-55.

79. Koch TG, Berg LC, Betts DH: Concepts for the clinical use of stem cells in equine medicine. Can Vet J 2008, 49:1009-1017.

80. Lindroos B, Maenpaa K, Ylikomi T, Oja H, Suuronen R, Miettinen S: Characterisation of human dental stem cells and buccal mucosa fibroblasts. Biochem Biophys Res Commun 2008, 368:329-335.

81. Violini S, Ramelli P, Pisani LF, Gorni C, Mariani P: Horse bone marrow mesenchymal stem cells express embryo stem cell markers and show the ability for tenogenic differentiation by in vitro exposure to BMP-12. BMC Cell Biol 2009, 10:29.

82. de Mattos Carvalho A, Alves AL, Golim MA, Moroz A, Hussni CA, de Oliveira PG, Deffune E: Isolation and immunophenotypic characterization of mesenchymal stem cells derived from equine species adipose tissue. Vet Immunol Immunopathol 2009, 132:303-306

83. Martinello T, Bronzini I, Maccatrozzo L, lacopetti I, Sampaolesi M, Mascarello F, Patruno M: Cryopreservation does not affect the stem characteristics of multipotent cells isolated from equine peripheral blood. Tissue Eng Part C Methods 2010, 16:771-781.

84. Bourzac C, Smith LC, Vincent P, Beauchamp G, Lavoie JP, Laverty S: Isolation of equine bone marrow-derived mesenchymal stem cells: a comparison between three protocols. Equine Vet J 2010, 42:519-527.

85. Muylle S: Aging. In Equine dentistry.. 3 edition. Edited by: Baker GJ, Easley J. Edinburgh, London, New York: Elsevier Saunders; 2010:55-66.

86. Burry RW: Specificity controls for immunocytochemical methods. J Histochem Cytochem 2000, 48:163-166.
87. Bills CE, Eisenberg H, Pallante SL: Complexes of organic acids with calcium phosphate: the Von Kossa stain as a clue to the composition of bone mineral. Johns Hopkins Med J 1974, 128:194-207.

88. Bosnakovski D, Mizuno M, Kim G, Takagi S, Okumura M, Fujinaga T: Isolation and multilineage differentiation of bovine bone marrow mesenchymal stem cells. Cell Tissue Res 2005, 319:243-253.

doi:10.1186/1746-6148-7-42

Cite this article as: Mensing et al.: Isolation and characterization of multipotent mesenchymal stromal cells from the gingiva and the periodontal ligament of the horse. BMC Veterinary Research 2011 7:42.

\section{Submit your next manuscript to BioMed Central and take full advantage of:}

- Convenient online submission

- Thorough peer review

- No space constraints or color figure charges

- Immediate publication on acceptance

- Inclusion in PubMed, CAS, Scopus and Google Scholar

- Research which is freely available for redistribution

Submit your manuscript at www.biomedcentral.com/submit
C) Biomed Central 